\title{
ARTICLE
}

Cite this: DOI: $10.1039 / \times 0 \times x 00000 x$

\section{One-step Synthesis of Nitrogen-doped microporous Carbon as Metal-Free Electrocatalyst for Oxygen Reduction Reaction}

Received 00th January 2014, Accepted 00th January 2014

DOI: $10.1039 / \times 0 \times x 00000 x$

www.rsc.org/

\author{
Xiaojun Zhao, ${ }^{a b c}$ Huanyu Zhao, ${ }^{a b}$ Tingting Zhang, ${ }^{b}$ Xuecheng Yan, ${ }^{a}$ Ye Yuan, ${ }^{b}$ \\ Haimin Zhang, ${ }^{d}$ Huijun Zhao, ${ }^{d}$ Daming Zhang ${ }^{c}$ Guangshan Zhu, ${ }^{a b}$ and \\ Xiangdong $\mathrm{Yao}^{* a}$
}

In our work, a convenient preparation route is reported for the synthesis of nitrogen-doped microporous carbon materials by direct carbonization of an amine functionalized aluminiumbased metal-organic framework (MOF) compound, amino-MIL-53(Al). Through the pore distribution and pore volume calculations, the carbon products possess narrow pore size, which is approximate $1 \mathrm{~nm}$, and high microporous surface area and volume. The highest proportion of microporous contribution is $93 \%$ for surface area and $88 \%$ for pore volume. As metal-free electrocatalysts, these carbon products exhibit attractive capability for oxygen reduction reaction (ORR) in alkaline medium. The investigation shows that these nitrogen-doped microporous carbon materials should have promising application for fuel cell.

\section{Introduction}

As one of the most popular functional materials, porous carbons have been concentrated much attention for numerous applications, such as electrocatalysts, electrochemical capacitors, fuel cells, metal-air batteries, lithium ion batteries, adsorbents and catalyst supports. ${ }^{1-12}$ To obtain porous carbon materials, many synthetic methods have been used, including pyrolysis, ${ }^{13-15}$ physical or chemical activation, ${ }^{16-18}$ chemical vapour decomposition, ${ }^{19}$ template carbonization, ${ }^{20-24}$ nanocasting, ${ }^{25}$ and laser ablation. ${ }^{26}$ Although many porous carbon materials have been gained, most of them belongs to mesoporous or macroporous, even disordered structure, which limits their performance as functional materials, especially for electrochemical materials. Therefore, more efforts have been devoted to obtain porous carbon with narrower pore size in microporous level.

In the past two decades, metal organic frameworks (MOFs) have been investigated widely due to their controllable framework structures, ordered channels, various topologies

${ }^{a}$ Queensland Micro- and Nanotechnology Centre, Griffith University, Nathan QLD 4111, Australia. ${ }^{b}$ State Key Laboratory of Inorganic Synthesis \& Preparative Chemistry, Jilin University, Changchun 130012, China. ${ }^{c}$ College of Electronic Science \& Engineering, Jilin University, Changchun 130012, China. ${ }^{d}$ Centre for Clean Environment and Energy, Gold Coast Campus, Griffith University, QLD 4222, Australia

E-mail:g.zhu@griffith.edu.au; x.yao@griffith.edu.au.

$\dagger$ Electronic Supplementary Information (ESI) available: TG curve, WXRD patterns, linear sweep voltammograms. See DOI: $10.1039 / \mathrm{b} 000000 \mathrm{x} /$

the stable and regular pore structure consisting of the rigid and extensive applications on gas storage, ${ }^{27-28}$ separation, ${ }^{29-30}$ catalysis, ${ }^{31-32}$ luminescence, ${ }^{33-35}$ and drug delivery. ${ }^{36}$ Basing on organic ligands and metal centres, MOF compounds possess special superiority to prepare porous carbons. Recently, enormous interests have been focused on attempting to obtain ordered porous carbon materials by MOFs compounds as hard templates or precursors. ${ }^{37-40}$

In this work, we selected an amine functionalized Al-MOF, amino-MIL-53(Al), and then carbonized it directly to obtain microporous carbon materials. The carbon products own high surface area, narrow and uniform pore size and high ratio of the micro pores in the structure. Especially during carbonization procedure at high temperatures, the nitrogen atoms, which come from the amino groups of organic ligands, have converted into the doped atoms in the carbon products, which may be beneficial for oxygen reduction reaction (ORR).

The ORR is one of the most crucial factors determining the performance of a fuel cell, which is an important application field of electrochemical catalysts. Although platinum-based materials display outstanding performance for ORR, the high cost and scarcity of platinum prohibit the widespread application in fuel cell. It is urgent to exploit inexpensive and high efficient catalysts as the substitution of platinum-based materials. Due to high surface area, volume capacity, low cost and good stability, ${ }^{41-43}$ High enthusiasm has been paid to enhance the capability of porous carbons as the popular metalfree electrochemical catalysts for ORR. According to the literatures reported previously, doped heteroatoms in the carbon frameworks are beneficial to enhance oxygen reduction performance of carbon catalysts. ${ }^{41,44-49}$ Nitrogen atom, which size is similar to the carbon atom, is the most popular specie used to synthesize heteroatoms doped carbon materials since it enhances the electron-donor or basic capacities of the carbon 
material and exhibits superior activity and stability. ${ }^{50-65}$ On the basis of our experiment, the as-prepared $\mathrm{N}$-doped microporous carbon materials display favourable performance for ORR as an electrocatalyst.

\section{Experimental}

\section{Reagents and Materials}

All chemicals purchased are reagent grade or better and were used without further purification.

Platinum on graphitized carbon $(\mathrm{Pt} / \mathrm{C}$, wt $20 \%)$, Naflon ${ }^{\circledR} 117$ solution (5\%) and Aluminum nitrate nonahydrate $(\geq 98 \%)$ are purchased from Sigma-Aldrich. 2aminoterephthalic acid (99\%) is purchased from Alfa Aesar.

\section{Preparation of amino-MIL-53(Al)}

Amino-MIL-53(Al) compound was prepared basing on the reported literature. ${ }^{66} \quad \mathrm{Al}\left(\mathrm{NO}_{3}\right)_{3} \cdot 9 \mathrm{H}_{2} \mathrm{O} \quad(493.6 \mathrm{mg}), 2$, aminoterephthalate acid $\left(\mathrm{NH}_{2}-\mathrm{H}_{2} \mathrm{BDC}, 375.6 \mathrm{mg}\right)$ and deionized water $(5 \mathrm{~mL})$ were mixed with the molar rate $\mathrm{Al}^{3+}$ : $\mathrm{NH} 2-\mathrm{H}_{2} \mathrm{BDC}: \mathrm{H}_{2} \mathrm{O}$ of 1: 1: 153. By dispensing to $27 \mathrm{~mL}$ Teflon-lined stainless steel vessels, the mixture was heated at $150{ }^{\circ} \mathrm{C}$ for 5 hours under autogenous pressure. After filtering and washing with deionized water for several times, yellow powder was obtained.

\section{Synthesis of microporous carbon PC-Al-n}

With a heating rate of $5{ }^{\circ} \mathrm{C} \cdot \mathrm{min}^{-1}, 400 \mathrm{mg}$ of amino-MIL53(Al) powders were heated at $120^{\circ} \mathrm{C}$ for 3 hours in order to remove solvent molecules in the framework and carbonized at $600,700,800,900$ and $1000{ }^{\circ} \mathrm{C}$ for 5 hours under nitrogen flow, respectively. After the above process, the carbonized sample was cooled to room temperature with $2{ }^{\circ} \mathrm{C} \cdot \mathrm{min}^{-1}$ rate. Then, primary product was immersed in hydrofluoric acid $(20 \%, 5 \mathrm{~mL})$ and stirred for 20 hours to eliminate $\mathrm{Al}$ particles. After repeating acid treatment for three times, the black powders were washed with $\mathrm{NaOH}$ aqueous solution $(0.1 \mathrm{M})$ and deionized water, centrifuged and dried at $80{ }^{\circ} \mathrm{C}$. The products were collected and denoted as PC-Al- $n(n=600,700$, 800,900 and 1000) by different carbonized temperatures.

\section{Instruments and characterization}

The $\mathrm{N}_{2}$ adsorption and desorption isotherm was measured on a Micromeritics Tristar II 3020 analyser. TG analysis was performed using a Netzch STA 449 F3 Jupiter thermogravimetric analyser at a heating rate of $5^{\circ} \mathrm{C} \cdot \min ^{-1}$ in $\mathrm{N}_{2}$ atmosphere. Wide-angle X-ray diffraction patterns (WXRD) was recorded by a Riguku D/MAX2550 diffractometer using $\mathrm{Cu}-\mathrm{Ka}$ radiation, $50 \mathrm{kV}, 200 \mathrm{~mA}$ with a scanning rate of $1^{\circ} \cdot \mathrm{min}^{-1}$. Measurements for Cyclic Voltammetry (CV), Rotating Disk Electrode (RDE) and Rotating Ring-Disk Electrode (RRDE) were carried out by a CHI 760D workstation ( $\mathrm{CH}$ Instruments) in a three-electrode electrochemical cell by glassy carbon (GC) electrode as the working electrode, $\mathrm{Pt}$ wire as counter electrodes and $\mathrm{Ag} / \mathrm{AgCl}$ as reference electrodes.

\section{Electrochemical Measurements}

The serosities of carbon catalysts and $\mathrm{Pt} / \mathrm{C}$ were prepared by same method. The catalyst powder $(1 \mathrm{mg})$ was dispersed in 1 $\mathrm{mL}$ mixed solution of $5 \mathrm{wt} \% \mathrm{Nafion} / \mathrm{ethanol} / \mathrm{water} /$ with the $\mathrm{v} / \mathrm{v}$ rate of 1: $15: 34$. The catalyst serosity $(12 \mu \mathrm{L}$ for $\mathrm{RDE}$ and $20 \mu \mathrm{L}$ for RRDE) was loaded onto a GC electrode of $5 \mathrm{~mm}$ in diameter and dried at $60{ }^{\circ} \mathrm{C}$ for $10 \mathrm{~min}$. Before every measurement beginning, the electrolyte, which is $0.1 \mathrm{M} \mathrm{KOH}$ aqueous solution, was saturated with $\mathrm{O}_{2}$, and $\mathrm{O}_{2}$ flow kept bubbling during the whole measurement process in order to maintain $\mathrm{O}_{2}$-saturated style.

Cyclic Voltammetry $(\mathrm{CV})$. The GC electrode as a working electrode was scanned at a rate of $100 \mathrm{mV} \cdot \mathrm{s}^{-1}$ in the potential range from 0.2 to $-1.2 \mathrm{~V}$ (vs. $\mathrm{Ag} / \mathrm{AgCl})$.

Rotating Disk (Electrode (RDE) Measurement. The catalyst modified working electrode was prepared by the method as above. The working electrode rotated with varying speed from 400 to $2500 \mathrm{rpm}$ at a scanned rate of $10 \mathrm{mV} \cdot \mathrm{s}^{-1}$.

Rotating Ring-Disk Electrode (RRDE) Measurement. For the RRDE measurements, catalyst serosities and electrodes were prepared by the same method. With a rotating speed of $1600 \mathrm{rpm}$, the disk electrode was scanned at a rate of 10 $\mathrm{mV} \cdot \mathrm{s}^{-1}$, and the potential of the ring electrode was constant at $0.5 \mathrm{~V}$ (vs. $\mathrm{Ag} / \mathrm{AgCl})$.

\section{Results and discussion}

According to previous literature, free $\mathrm{NH}_{2}-\mathrm{H}_{2} \mathrm{BDC}$ molecules should reside in porous channels of the synthesized amino-MIL-53(Al) compound. $^{66}$ Thus, these guest organic molecules would provide abundant nitrogen source for doping nitrogen atoms directly into carbon materials through carbonization. In order to confirm the amount of guest $\mathrm{NH}_{2}$ $\mathrm{H}_{2} \mathrm{BDC}$ molecules, TG analysis of amino-MIL-53(Al), which was synthesized in this work, was performed under helium flow with a heating rate of $5^{\circ} \mathrm{C} \cdot \mathrm{min}^{-1}$. As shown in Fig. S1, the compounds exhibit a two-step weight loss. The first step is due to the release of the guest $\mathrm{NH}_{2}-\mathrm{H}_{2} \mathrm{BDC}$ in the pores, and the second one corresponds to the decomposition of the ligands from the frameworks. The curve and result are accordant with that reported previously. ${ }^{66}$

When the MOF compounds was heated at high temperatures, amino groups of the organic ligands converted into doped atoms in carbon products. At different temperatures, Al-MOF compounds were carbonized directly under nitrogen flow and five microporous carbon materials were obtained. We denoted them as PC-Al- $n$ ( $n=600,700,800,900$ and 1000, respectively) by different carbonized temperatures. The structure of the carbon products was characterized by wideangle XRD (WXRD) analysis at room temperature with a scanned range of $10-80^{\circ}$. As shown in Fig. S2, the peak at $24^{\circ}$ and $44^{\circ}$, which belong to interlayer peaks of graphitic carbon, were observed in all patterns. Compared with the pattern of PC-A1-800-u (Fig. S2(a)), which notes the product of AMINOMIL-53(AL) carbonized at $800^{\circ} \mathrm{C}$ without hydrofluoric acid treatment, the peaks of alumina disappeared in the patterns of PC-Al- $n$ samples (Fig. S2(b), (c), (d), (e) and (f)). The result signifies alumina removed after acid treatment, and the final products were metal-free carbons. 
Table 1. Textural parameters of PC-Al-n series calculated by $\mathrm{N}_{2}$ adsorption

\begin{tabular}{|c|c|c|c|c|c|}
\hline Sample & $\begin{array}{c}\mathrm{S}_{\mathrm{BET}}{ }^{\text {[a] }} \\
\left(\mathrm{m}^{2} \cdot \mathrm{g}^{-1}\right)\end{array}$ & $\begin{array}{l}S_{\text {micro }}{ }^{[b]} \\
\left(m^{2} \cdot g^{-1}\right)\end{array}$ & $\begin{array}{c}\text { Pore } \\
\text { Size }^{[\mathrm{c}]} \\
(\AA) \\
\end{array}$ & $\begin{array}{c}V_{\text {total }}^{[d]} \\
\left(\mathrm{cm}^{3} \cdot \mathrm{g}^{-1}\right)\end{array}$ & $\begin{array}{c}V_{\text {micro }}^{[e]} \\
\left(\mathrm{cm}^{3} \cdot \mathrm{g}^{-1}\right)\end{array}$ \\
\hline PC-Al-600 & 1030 & 891 & 10.9 & 0.48 & 0.35 \\
\hline PC-Al-700 & 1418 & 1276 & 10.9 & 0.61 & 0.49 \\
\hline PC-Al-800 & 1588 & 1476 & 10.9 & 0.65 & 0.57 \\
\hline PC-Al-900 & 1448 & 1151 & 10.9 & 0.71 & 0.49 \\
\hline PC-Al-1000 & 1172 & 577 & 11.8 & 0.97 & 0.31 \\
\hline
\end{tabular}

[a] $\mathrm{S}_{\mathrm{BET}}$ is the surface area calculated by Brunauer-Emmett-Teller equation. [b] $\mathrm{S}_{\text {micro }}$ is microporous surface area calculated by t-plot method. ${ }^{[c]}$ Pore size distribution is calculated by density functional theory (DFT). ${ }^{[d]}$ Total pore volume is calculated at a relative pressure of 0.96 . $^{\text {[e] }}$ Micro-pore volume is calculated by t-plot method.
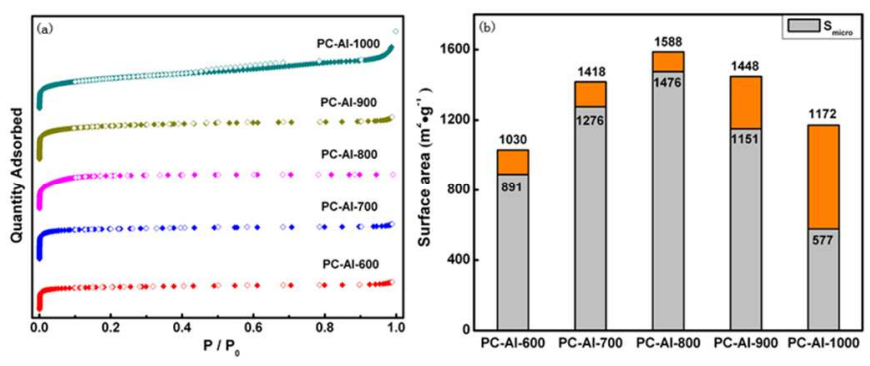

Figure 1. Nitrogen adsorption curves (a) and surface area (b) and of PC-Al-n samples

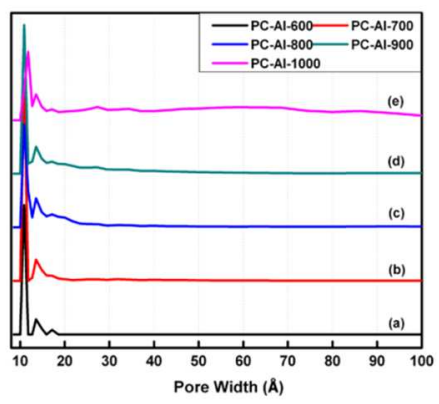

Figure 2. Pore size distribution of PC-Al- $n$ samples

In order to explore the pore structure of PC-Al- $n$ samples, the nitrogen adsorption and desorption isotherms were recorded at $77 \mathrm{~K}$ (Fig. 1(a)). The curves of PC-Al- $n$ samples exhibit typical Type-I sorption isotherm except PC-Al-1000, that is similar to Type-IV isotherm. The further investigation is focused on the calculation of surface area, pore size distribution and pore volume, and the data were displayed in Table 1. The pore size of PC-Al-600 900 distributes at $1.1 \mathrm{~nm}$ and enlarges to $1.2 \mathrm{~nm}$ for PC-Al-1000 (Fig. 2). The total surface area, microporous surface area and volume were calculated by Brunauer-Emmett-Teller (BET) method and $\mathrm{t}$ plot method, respectively. The results indicate microporous structure contribute the major surface area and volume for PCAl-600 900. The rate of $\mathrm{S}_{\text {micro }} / \mathrm{S}_{\text {total }}$ goes up from 0.87 to 0.93 and finally falls down to 0.50 (PC-Al-1000). The variation is similar for pore volume rate, and highest value of $\mathrm{V}_{\text {micro }} / \mathrm{V}_{\text {total }}$ is 0.88 for PC-Al-800. BET surface area and total volume of PC-Al-800 are $1588 \mathrm{~m}^{2} \cdot \mathrm{g}^{-1}$ and $0.65 \mathrm{~cm}^{3} \cdot \mathrm{g}^{-1}$ respectively, and $1476 \mathrm{~m}^{2} \cdot \mathrm{g}^{-1}$ of surface area and $0.57 \mathrm{~cm}^{3} \cdot \mathrm{g}^{-1}$ of pore volume originate from microporous structure. PC-Al-
800 is a wonderful microporous carbon material with high surface area, whereas the main pore structures of the MOFderived carbon materials reported previously are mesoporous and macroporous forms. ${ }^{67-73}$

Compared the surface area and volume of PC-Al- $n$ samples, it is suggested that $800{ }^{\circ} \mathrm{C}$ is a suitable temperature to form micropous structure. By heating the amino-MIL-53(Al) compounds in the range of 600 to $800{ }^{\circ} \mathrm{C}$, the surface area and microporous structure of the products increase continually, nevertheless, going on raising the temperature until $1000{ }^{\circ} \mathrm{C}$, the surface area decreases and the pore size becomes wider. When amino-MIL-53(Al) was carbonized at $800{ }^{\circ} \mathrm{C}$, the microporous surface area and volume of the carbon product reached the maximum. In contrast, the total pore volume of the carbon products increases continually. It can be considered that the wider pores support broader space and higher pore volume.

The nitrogen content and state of PC-Al- $n$ samples were measured by X-ray photoelectron spectroscopy (XPS) and the results were listed in Table S1. As shown in Fig.3, total nitrogen contents of the products decrease distinctly with raising the heating temperature. This decline may be explained that high temperature is beneficial for nitrogen and oxygen atoms combined to generate gaseous oxide during carbonization process. The bond energy peaks of $\mathrm{N} 1 \mathrm{~s}$ scan spectra at 398.6, 400.7 and $401.6 \mathrm{eV}$ are fitted into pyridinic$\mathrm{N}$, pyrrolic-N and graphitic-N, respectively (Fig.4). The XPS results display the detail of nitrogen conversion: amino groups of $\mathrm{NH}_{2}-\mathrm{H}_{2} \mathrm{BDC}$ convert into the pyridinic- $\mathrm{N}$ and pyrrolic- $\mathrm{N}$ form when amino-MIL-53(Al) is heated at a relative lower temperature and then graphiticn-N state is formed at a higher temperature.

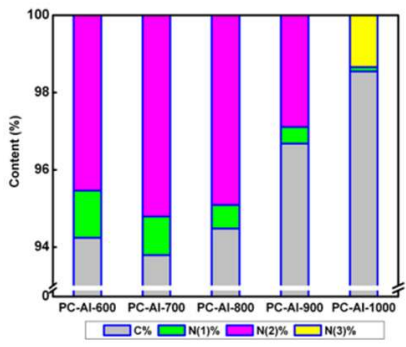

Figure 3. Nitrogen and carbon contents of PC-Al- $n$ samples

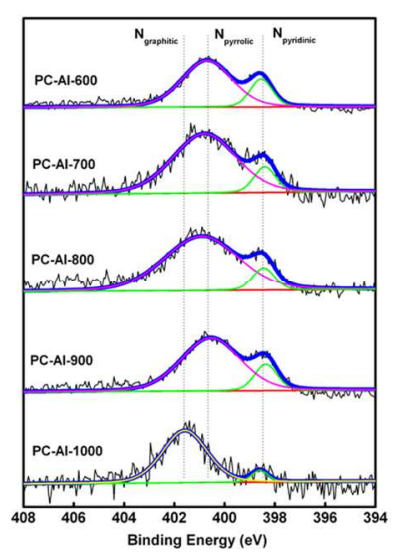

Figure 4. XPS spectra of $\mathrm{N} 1 \mathrm{~s}$ narrow scan of PC-Al- $n$ samples 
The performance as electrochemical catalysts for oxygen reduction reaction (ORR) was investigated by cyclic voltammetry $(\mathrm{CV})$, rotating disk electrode (RDE) and rotating ring-disk electrode (RRDE) voltammetry. All the examinations were carried out with a three-electrode system in $\mathrm{O}_{2}$-saturated alkaline medium. For the three-electrode cell, glassy carbon (GC) electrode, $\mathrm{Pt}$ wine and $\mathrm{Ag} / \mathrm{AgCl}$ electrode were used by working, counter and reference electrode, respectively. $\mathrm{CV}$ measurements were recorded at a scanned rate of $100 \mathrm{mV} \cdot \mathrm{s}^{-1}$ and in a potential range from $-1.2 \sim 0.2 \mathrm{~V}$ (vs. $\mathrm{Ag} / \mathrm{AgCl}$ ). As a comparison, the $\mathrm{CV}$ curves of PC-Al- $n$ series and $\mathrm{Pt} / \mathrm{C}(20 \mathrm{wt} \%)$ are given in Fig.5. In $\mathrm{O}_{2}$-saturated $\mathrm{KOH}$ aqueous solution $(0.1 \mathrm{M})$, a characteristic reduction peak is exhibited at $-0.29 \sim-0.25 \mathrm{~V}$ for PC-Al- $n$ samples and -0.19 $\mathrm{V}$ for $\mathrm{Pt} / \mathrm{C}$. A remarkable shift can be observed between PCAl-600 and other samples, and for PC-Al-700 1000 sample, the reduction peaks concentrate is closed to $-0.25 \mathrm{~V}$. Compared PC-Al-600 with PC-Al-700 1000, the positive shift of reduction peak suggests that higher surface area and specific nitrogen state enhance the oxygen reduction performance of the catalysts.

Linear sweep voltammograms (LSV) was measured on a RDE at a scanned rate of $10 \mathrm{mV} \cdot \mathrm{s}^{-1}$ and rotating speed of 400 , 600, 900, 1225, 1600, 2025 and $2500 \mathrm{rpm}$, respectively (Fig. S3). As shown in Fig.6, the onset potentials of PC-Al- $n$ series for ORR shifted obviously towards positive potential with carbonized temperature rising. When the current density achieves $-0.1 \mathrm{~mA} \cdot \mathrm{cm}^{-2}$, the highest onset potential at $-0.13 \mathrm{~V}$ for PC-Al-1000 shifts approximately $0.10 \mathrm{~V}$ compared to PC$\mathrm{Al}-600$ and is close to $\mathrm{Pt} / \mathrm{C}(-0.07 \mathrm{~V})$. The potential difference between $\mathrm{PC}-\mathrm{Al}-1000$ and $\mathrm{Pt} / \mathrm{C}$ is only $0.06 \mathrm{~V}$. The lowest content of $\mathrm{N}$ sample exhibits the highest on-set potential. The mechanism is unclear and needs to be further investigated. LSV curves are also investigated by Koutecky-Levich plots $\left(J^{l}\right.$ vs. $\left.\omega^{-1 / 2}\right)$ at various electrode potentials from -0.35 to -0.7 $\mathrm{V}$ (vs. $\mathrm{Ag} / \mathrm{AgCl})$. The slopes of the best linear fit lines are used to calculate the number of electrons transferred (n) per $\mathrm{O}_{2}$ molecule from Koutecky-Levich equation:

$$
\frac{1}{J}=\frac{1}{J_{L}}+\frac{1}{J_{k}}=\frac{1}{B \omega^{1 / 2}}+\frac{1}{J_{k}}
$$

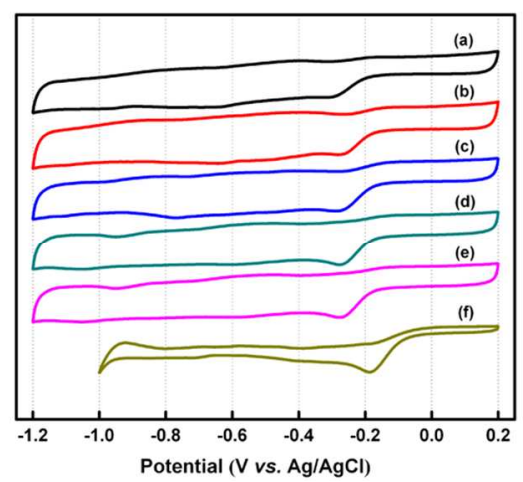

Figure 5. Cyclic Voltammograms obtained in oxygen-saturated 0.1 M KOH solution for PC-Al-600 (a), 700 (b), 800 (c), 900 (d), 1000 (e) and $20 \% \mathrm{Pt} / \mathrm{C}(\mathrm{f})$.

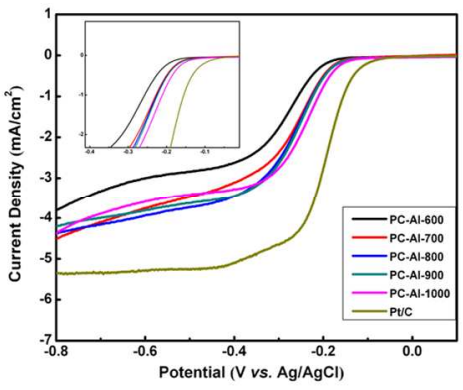

Figure 6. LSV curves of the carbon products and Pt/C in oxygensaturated $0.1 \mathrm{M} \mathrm{KOH}$ solution at a rotation speed of $1600 \mathrm{rpm}$ and a scanning rate of $10 \mathrm{mV} \cdot \mathrm{s}^{-1}$.

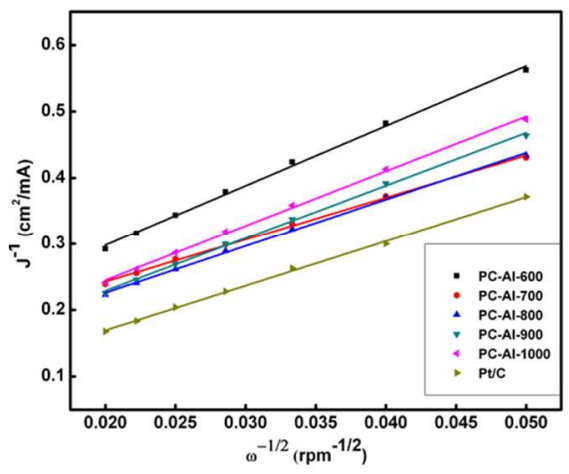

Figure 7. Koutecky-Levich plots of the carbon products and $\mathrm{Pt} / \mathrm{C}$ at a potential of $-0.55 \mathrm{~V}$. The plots are generated from the LSV curves of all the samples tested in oxygen-saturated $0.1 \mathrm{M} \mathrm{KOH}$ solution with different rotating speeds.

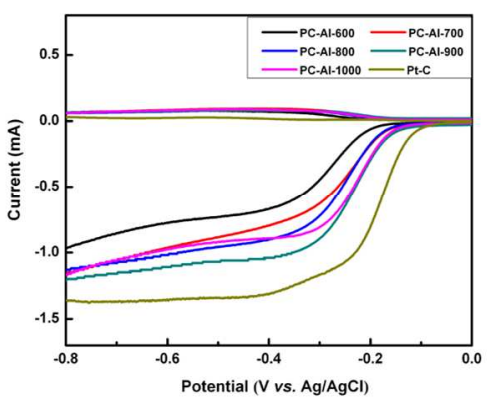

Figure 8. Rotating Ring-Disk Electrode (RRDE) spectra for PC-Al- $n$ samples and $\mathrm{Pt} / \mathrm{C}$ in oxygen -saturated $0.1 \mathrm{M} \mathrm{KOH}$ solution. Linear sweep voltammetry (LSV) was performed at a rotating speed of $1600 \mathrm{rpm}$ and a scan rate of $10 \mathrm{mV} \cdot \mathrm{s}^{-1}$, and the Pt ring electrode was polarized to oxidize the $\mathrm{HO} 2$ - intermediates collected from the modified GC disk electrode at $0.5 \mathrm{~V}$.

where $J$ is the measured current density, $J_{L}$ and $J_{K}$ are the diffusion-limiting and kinetic current densities, and $\omega$ is the rotating speed. $B$ is the Levich slope given by

$$
\mathrm{B}=0.2 n \mathrm{~F}\left(\mathrm{D}_{\mathrm{O} 2}\right)^{2 / 3}(v)^{-1 / 6} \mathrm{C}_{\mathrm{O} 2}
$$

$n$ represents the number of electrons transferred per $\mathrm{O}_{2}$ molecule, $\mathrm{F}$ is the Faraday constant $\left(\mathrm{F}=96485 \mathrm{C} \cdot \mathrm{mol}^{-1}\right), \mathrm{D}_{\mathrm{O} 2}$ is the diffusion coefficient of $\mathrm{O}_{2}$ in $0.1 \mathrm{M} \mathrm{KOH}$ aqueous solution $\left(1.9 \times 10^{-5} \mathrm{~cm}^{2} \cdot \mathrm{s}^{-1}\right), v$ is the kinetic viscosity of 
electrolyte $\left(0.01 \mathrm{~cm}^{2} \cdot \mathrm{s}^{-1}\right), \mathrm{C}_{\mathrm{O} 2}$ is the bulk concentration of $\mathrm{O}_{2}$ $\left(1.2 \times 10^{-6} \mathrm{~mol} \cdot \mathrm{cm}^{-3}\right)$.

The Koutecky-Levich plots of all carbon products and $\mathrm{Pt} / \mathrm{C}$ at a potential of $-0.55 \mathrm{~V}$ are shown in Fig. 7. It is evident that the carbon products perform excellent electrocatalytic activity in alkaline electrolyte. The numbers of electron transferred per $\mathrm{O}_{2}$ molecule at $-0.55 \mathrm{~V}$ are calculated and listed in Table S2. It is an effective four-electron transferred process for PC-Al-700, 800 and 900 . Moreover, to compare the kinetic current density $\left(J_{K}\right)$ for the carbon catalysts, PC-Al-900 is nearly twice than PC-A1-600 and higher than rest of the samples. The higher surface area provides more reactive area and active sites for oxygen reduction and is beneficial for oxygen reduction performance as the electrocatalyst, ${ }^{48}$ such as higher numbers of electron transferred and the kinetic current density (Fig. S4 and Table S2).

In addition, RRDE was also used to evaluate the performance of the PC-Al- $n$ samples for ORR and the results are shown in Fig. 8. The experiment was tested at a scanned rate of $10 \mathrm{mV} \cdot \mathrm{s}^{-1}$ and rotating speed of $1600 \mathrm{rpm}$ for RRDE. PC-Al-700, 800 and 900 display attractive catalytic activity and selectivity in $\mathrm{O}_{2}$-saturated $\mathrm{KOH}$ aqueous solution. The performance of PC-Al- $n$ samples for ORR on RDE and RRDE suggests that higher surface area and doped-nitrogen for catalysts is an advantage of oxygen reduction in a fuel cell. ${ }^{46}$

\section{Conclusions}

In summary, we reported a simple and convenient approach for preparing nitrogen-doped microporous carbon materials. It is a one-step process, during which MOF compound was converted to carbon and nitrogen atoms were doped into the carbon products at the same time. We investigated systematically the pore structure and electrocatalytic ability of five carbon products by various characterization methods. These products possess narrow pore size, high microporous surface area and microporous volume. As a metal-free electrochemical catalyst, high surface area and the doped nitrogen atoms may promote the performance of the microporous carbon products for ORR, which is one of the most crucial factors to determine the performance of a fuel cell. These carbon products exhibit excellent oxygen reduction capability in alkaline medium.

\section{Acknowledgements}

We are grateful for the financial support of Future Fellowship of the Australian Research Council.

\section{Reference}

1 L. L.Zhang, X. S. Zhao, Chem. Soc. Rev., 2009, 38, 2520.

2 A. Stein, Z. Wang, M. A. Fierke, Adv. Mater., 2009, 21, 265.

3 N. A. Kaskhedikar, J. Maier, Adv. Mater., 2009, 21, 2664.

4 Y. Xia, Z. Yang, R. Mokaya, Nanoscale, 2010, 2, 639.

5 M. Inagakia, H. Konnoa, O. Tanaike, J. Power Sources, 2010, 195, 7880.

6 Y. Yang, K. Chiang, N. Burke, Catal. Today, 2011, 178, 197.

7 Y. Zhai, Y. Dou, D. Zhao, P. F. Fulvio, R. T. Mayes, S. Dai, $A d v$. Mater., 2011, 23, 4828.

8 R. Marom, S. F. Amalraj, N. Leifer, D. Jacob, D. Aurbach, J. Mater. Chem., 2011, 21, 9938.
9 H. Nishihara, T. Kyotani, Adv. Mater., 2012, 24, 4473.

10 S. J. Yang, H. Jung, T. Kim, C. R. Park, Prog. Nat. Sci.: Mater. Inter., 2012, 22, 631.

11 D. Wang, Q. Zeng, G. Zhou, L. Yin, F. Li, H. Cheng, I. R. Gentle, G. Q. Lu, J. Mater. Chem. A, 2013, 1, 9382.

12 H. Jiang, P. S. Lee, C. Li, Energy Environ. Sci., 2013, 6, 41.

13 C. Liang, S. Dai, Chem. Mater., 2009, 21, 2115.

14 X. Wang, J. S. Lee, C. Tsouris, D. W. DePaoli, S. Dai, J. Mater. Chem., 2010, 20, 4602.

15 M. C. Gutiérrez, D. Carriazo, C. O. Ania, J. B. Parra, M. L. Ferrera, F. del Monte, Energy Environ. Sci., 2011, 4, 3535.

16 H. Wang, Q. Gao, J. Hu, J. Am. Chem. Soc., 2009, 131,7016.

17 M. Sevilla, N. Alam, R. Mokaya, J. Phys. Chem. C, 2010, 114, 11314.

18 M. Sevilla, R. Mokaya, A. B. Fuertes, Energy Environ. Sci., 2011, 4, 2930.

19 B. Zheng, C. Lu, G. Gu, A. Makarovski, G. Finkelstein, J. Liu, Nano Letters, 2002, 2, 895.

20 H. Yang, D. Zhao, J. Mater. Chem., 2005, 15, 1217.

21 F. Zhang, Y. Meng, D. Gu, Y. Yan, C. Yu, B. Tu, D. Zhao, J. Am. Chem. Soc., 2005, 127, 13508.

22 Y. Meng, D. Gu, F. Zhang, Y. Shi, H. Yang, Z. Li, C. Yu, B. Tu, D. Zhao, Angew. Chem. Int. Ed., 2005, 44, 7053.

23 Y. Deng, Y. Cai, Z. Sun, D. Gu, J. Wei, W. Li, X. Guo, J. Yang, D. Zhao, Adv. Funct. Mater., 2010, 20, 3658.

24 D. Feng, Y. Lv, Z. Wu, Y. Dou, L. Han, Z. Sun, Y. Xia, G. Zheng, D. Zhao, J. Am. Chem. Soc., 2011, 133, 15148.

25 T. W. Kim, I. S. Park, R. Ryoo, Angew. Chem., Int. Ed., 2003, 42, 4375.

26 A. Thess, R. Lee, P. Nikolaev, H. Dai, P. Petit, J. Robert, C. Xu, Y. H. Lee, S. G. Kim, A. G. Rinzler, D. T. Colbert, G. E. Scuseria, D. Tománek, J. E. Fischer, R. E. Smalley, Science, 1996, 273, 483.

27 L.J. Murray, M. Dincâ, J. R. Long, Chem. Soc. Rev., 2009, 38, 1294.

28 T. A. Makal, J. R. Li, W. Lua, H. C. Zhou, Chem. Soc. Rev., 2012, 41, 7761.

29 P. D. C. Dietzel, V. Besikiotis R. Blom, J. Mater. Chem., 2009, 19, 7362.

30 J. R. Li, R. J. Kuppler, H, C. Zhou, Chem. Soc. Rev., 2009, 38, 1477.

31 A. Dhakshinamoorthy, M. Alvaroa, H. Garcia, Catal. Sci. Technol., $2011,1,856$.

32 A. Dhakshinamoorthy, H. Garcia, Chem. Soc. Rev., 2012, 41, 5262.

33 M. D. Allendorf, C. A. Bauer, R. K. Bhakta, R. J. T. Houk, Chem. Soc. Rev., 2009, 38, 1330.

34 C. G. Silva, A. Corma, H. García, J. Mater. Chem., 2010, 20, 3141.

35 Y. Cui, Y. Yue, G. Qian, B. Chen, Chem. Rev., 2012, 112, 1126.

36 J. D. Rocca, D. Liu, W. B. Lin, Acc. Chem. Res., 2011, 44, 957.

37 S. Lim, K. Suh, Y. Kim, M. Yoon, H. Park, D. N. Dybtsev, K. Kim, Chem. Commun., 2012, 48, 7447.

38 W. Chaikittisilp, K. Ariga, Y. Yamauchi, J. Mater. Chem. A, 2013, 1, 14.

39 N. L. Torad, M. Hu, Y. Kamachi, K. Takai, M. Imura, M. Naito, Y. Yamauchi, Chem. Commun., 2013, 49, 2521.

40 Q. Wang, W.i Xia, W. Guo, L. An, D. Xia, R. Zou, Chem. Asian J., 2013, 8, 1879.

41 Y. Shao, J. Sui, G. Yin, Y. Gao, Appl. Catal. B, 2008, 79, 89. 42 Y. Zheng, Y. Jiao, M. Jaroniec, Y. Jin, S. Qiao, Small, 2012, 8, 3550. 
43 R. Cao, J. Lee, M. Liu, J. Cho, Adv. Ener. Mater., 2012, 2, 816.

44 M. Zhang, L. Dai, Nano Energy, 2012, 1, 514.

45 C. H. Choi, S. H. Park, S. I. Woo, ACS Nano, 2012, 6, 7084.

46 Y. Zhao, L. Yang, S. Chen, X. Wang, Y. Ma, Q. Wu, Y. Jiang, W. Qian, Z. Hu, J. Am. Chem. Soc., 2013, 135, 1201.

47 N. Daems, X. Sheng, I. F. J. Vankelecom, P. P. Pescarmona, J. Mater. Chem. A, 2014, 2, 4085.

48 H. Huang, Xin Wang, J. Mater. Chem. A, 2014, 2, 6266.

49 X. Kong, C. Chen, Q. Chen, Chem. Soc. Rev., 2014, 43, 2841.

50 Y. Li, T. Hung, C. Chen, Carbon, 2009, 47, 850.

51 F. Su, Z. Tian, C. K. Poh, Z. Wang, S. H. Lim, Z. Liu, J. Lin, Chem. Mater., 2009, 22, 832.

52 Y. Wang, Y. Shao, D. W. Matson, J. Li, Y. Lin, ACS Nano, 2010, 4, 1790-1798.

53 Y. Zhou, K. Neyerlin, T. S. Olson, S. Pylypenko, J. Bult, H. N. Dinh, T. Gennett, Z. Shao, R. O'Hayre, Energ Environ. Sci., 2010, 3, 1437.

54 G. Liu, X. Li, P. Ganesan, B. N. Popov, Electrochim. Acta, 2010, 55, 2853.

55 D. Higgins, Z. Chen, Z. Chen, Electrochim. Acta, 2011, 56, 1570.

56 C. Pan, L. Qiu, Y. Peng, F. Yan, J. Mater. Chem., 2012, 22, 13578.

57 D. Geng, Y. Hu, Y. Li, R. Li, X. Sun, Electrochem. Commun., 2012, 22, 65 .

58 Y. Xin, J. Liu, X. Jie, W. Liu, F. Liu, Y. Yin, J. Gu, Z. Zou, Electrochim. Acta, 2012, 60, 354.

59 C. Hsu, P. Kuo, J. Power Sources, 2012, 198, 83.

60 K. Gong, F. Du, Z. Xia, M. Durstock, L. Dai, Science, 2009, 323, 760.

61 R. Liu, D. Wu, X. Feng, K. Müllen, Angew. Chem., Int. Ed., 2010, 49, 2565.

62 L. Qu, Y. Liu, J. Baek, L. Dai, ACS Nano, 2010, 4, 1321.

63 Z. Wang, R. Jia, J. Zheng, J. Zhao, L. Li, J. Song, Z. Zhu, ACS Nano, 2011, 2, 1677.

64 Y. Zhao, C. Hu, Y. Hu, H. Cheng, G. Shi, and L. Qu, Angew. Chem. Int. Ed., 2012, 51, 11371

65 S. Chen, J. Bi, Y. Zhao, L. Yang, C. Zhang, Y. Ma, Q. Wu, X. Wang, Z. Hu, Adv. Mater., 2012, 24, 5593.

66 T. Ahnfeldt, D. Gunzelmann, T. Loiseau, D. Hirsemann, J. Senker, G. Férey, N. Stock, Inorg. Chem., 2009, 48, 3057.

67 B. Liu, H. Shioyama, H. Jiang, X. Zhang, Q. Xu, Carbon, 2010, 48, 456.

68 J. Hu, H. Wang, Q. Gao, H. Guo, Carbon, 2010, 48, 3599.

69 M. Hu, J. Reboul, S. Furukawa, N. L. Torad, Q. Ji, P. Srinivasu, K. Ariga, S. Kitagawa, Y. Yamauchi, J. Am. Chem. Soc., 2012, 134, 2864.

70 W. Chaikittisilp, M. Hu, H. Wang, H. Huang, T. Fujita, K. C.-W. Wu, L. Chen, Y. Yamauchi, K. Ariga, Chem. Commun., 2012, 48, 7259.

71 P. Pachfule, B. P. Biswal, R. Banerjee, Chem. Eur. J., 2012, 18, 11399.

72 S. J. Yang, T. Kim, J. H. Im, Y. S. Kim, K. Lee, H. Jung, C. R. Park, Chem. Mater., 2012, 24, 464.

73 K. Xi, S. Cao, X. Peng, C. Ducati, R. V. Kumar, A. K. Cheetham, Chem. Commun., 2013, 49, 2192. 


\section{Journal of \\ Materials Chemistry A}

Accepted Manuscript

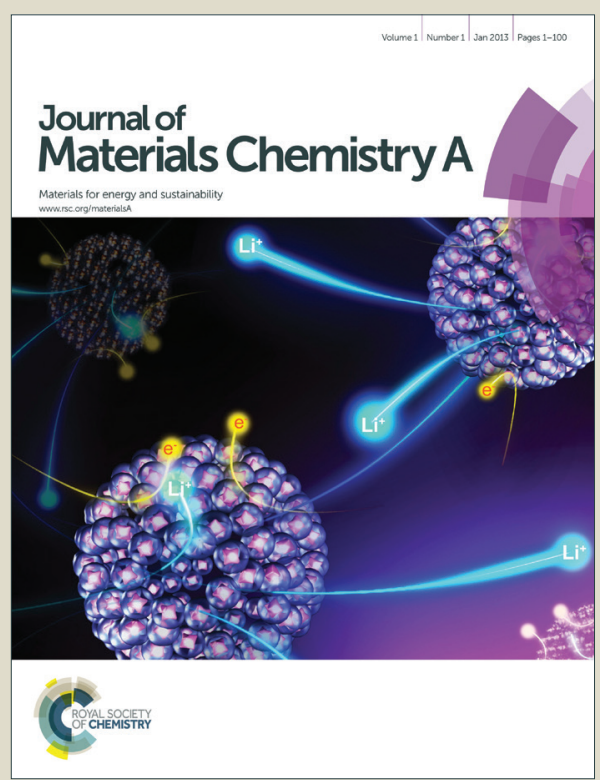

This is an Accepted Manuscript, which has been through the Royal Society of Chemistry peer review process and has been accepted for publication.

Accepted Manuscripts are published online shortly after acceptance, before technical editing, formatting and proof reading. Using this free service, authors can make their results available to the community, in citable form, before we publish the edited article. We will replace this Accepted Manuscript with the edited and formatted Advance Article as soon as it is available.

You can find more information about Accepted Manuscripts in the Information for Authors.

Please note that technical editing may introduce minor changes to the text and/or graphics, which may alter content. The journal's standard Terms \& Conditions and the Ethical guidelines still apply. In no event shall the Royal Society of Chemistry be held responsible for any errors or omissions in this Accepted Manuscript or any consequences arising from the use of any information it contains. 